\title{
PENINGKATAN KETERAMPILAN BERTANYA DAN HASIL BELAJAR SISWA KELAS 2 SDN SLUNGKEP 03 MENGGUNAKAN MODEL DISCOVERY LEARNING
}

\author{
Meiria Sylvi Astuti \\ keizykeizy001@gmail.com \\ Sekolah Dasar Negeri Slungkep 03 Kayen - Pati
}

\begin{abstract}
ABSTRAK
Tujuan penelitian ini adalah untuk mengembangkan langkah-langkah model Discovery Learning dalam rangka meningkatkan keterampilan bertanya dan hasil belajar siswa kelas 2 SDN Slungkep 03 pada tema tugasku sehari- hari. Jenis penelitian yang digunakan dalam penelitian ini adalah penelitian tindakan kelas, yang terdiri dari dua siklus. Masing-masing siklus terdiri atas tahapan perencanaan tindakan, pelaksanaan tindakan, observasi, dan refleksi. Instrumen pengumpulan data menggunakan rubrik penilaian keterampilan bertanya siswa, dan soal tes tema tugasku sehari-hari yang meliputi 3 mata pelajaran (Matematika, Bahasa Indonesia dan $\mathrm{PKn}$ ). Analisis data dilakukan dengan menggunakan analisis deskriptif komparatif yaitu membandingkan kondisi awal sebelum dilakukan tindakan, hasil siklus 1, dan siklus 2. Hasil penelitian menunjukkan bahwa langkah- langkah model Discovery Learning yang meliputi : a. Stimulation, b. Problem statement, c. Data collection, d. Data Processing, e. Verification, f. Generalization dapat meningkatkan keterampilan bertanya dan hasil belajar siswa kelas 2 SD Negeri Slungkep 03, Kayen- Pati. Peningkatan keterampilan bertanya siswa siklus I dari kategori sedang menjadi kategori tinggi diakhir siklus II sebesar $19,22 \%$. Sementara Jumlah siswa yang tuntas untuk muatan Bahasa Indonesia siklus I mencapai $73,33 \%$ menjadi $86,67 \%$ diakhir siklus II. Jumlah siswa yang tuntas untuk muatan PPKn dari siklus I sebesar 66,67\% menjadi 86,67\% diakhir siklus II. Sementara jumlah siswa tuntas untuk muatan Matematika, dari siklus I sebesar $46,67 \%$ menjadi $80,00 \%$ diakhir siklus II. Ketuntasan hasil belajar siswa tersebut mampu mencapai kategori tinggi rata- rata sebesar 18,19\%- 33,33\%.
\end{abstract}

Kata kunci: keterampilan bertanya, hasil belajar, model pembelajaran Discovery Learning.

\section{PENDAHULUAN}

Kurikulum SD/MI tahun 2013 menggunakan pendekatan tematik
integratif. Tema berperan sebagai pemersatu kegiatan pembelajaran dengan
memadukan beberapa muatan pelajaran sekaligus. Muatan pelajaran yang
dipadukan adalah muatan pelajaran PPKn, Bahasa Indonesia, IPS, IPA,


Matematika, Seni Budaya dan Prakarya, serta Pendidikan Jasmani, Olah Raga dan Kesehatan. Dalam Kurikulum 2013, tema dikembangkan menjadi subtema dan satuan pembelajaran (Mawardi, 2014: 2). Selain pendekatan tematik integratif, proses pembelajaran pada Kurikulum 2013 dilaksanakan menggunakan pendekatan saintifik. Proses pembelajaran menyentuh tiga ranah, yaitu sikap, pengetahuan dan keterampilan. Pendekatan saintifik merupakan pembelajaran yang mengadopsi langkah- langkah saintis dalam membangun pengetahuan melalui metode ilmiah. Kegiatan pembelajaran saintifik di-lakukan melalui proses mengamati, menanya, mencoba, mengasosiasi, dan mengomunikasi-kan.

Kegiatan pembelajaran tidak lepas dari kegiatan tanya jawab, baik itu antara siswa dengan guru atau antara siswa dengan siswa yang lain. Keterampilan bertanya merupakan salah satu keterampilan saintifik yang cukup penting. Keterampilan bertanya adalah cara penyampaian suatu pelajaran melalui interaksi dua arah yaitu dari guru kepada siswa dan dari siswa kepada guru agar diperoleh jawaban kepastian materi melalui jawaban lisan guru atau siswa.

Hasil observasi yang dilakukan di kelas 2 SDN. Slungkep 03 dalam kegiatan pembelajaran terutama ketika menjelaskan materi masih didominasi oleh penggunaan metode ceramah, tanya jawab dan kegiatan yang lebih berpusat pada guru. Aktivitas siswa dapat di katakan hanya mendengarkan penjelasan guru, mencatat hal-hal yang dianggap penting saja, dan menjawab pertanyaan jika ditunjuk, ada pula beberapa siswa yang mengantuk, bermalas-malasan dan melakukan kegiatan yang tidak ada hubungannya dengan pelajaran. Dengan kata lain implementasi pendekatan saintifik di dalam pembelajaran masih sulit dilakukan. Selain itu keterampilan bertanya siswa sangat rendah. Siswa jarang sekali mengajukan pertanyaan kepada guru selama proses pembelajaran berlangsung. Bila diajukan pertanyaan kepada mereka, hampir seluruh siswa tidak berani mengacungkan tangan untuk menjawab. Sebaliknya, bila diberi kesempatan untuk bertanya, jarang sekali ada siswa yang memanfaatkannya. Mereka tampaknya takut (tidak berani) mengajukan pertanyaan/ pendapat mengenai materi yang disampaikan.

Permasalahan yang terjadi dalam proses pembelajaran tematik, terutama di kelas 2 SDN Slungkep 03 Kabupaten Pati di atas menunjukkan siswa kurang antusias dan tertarik dengan proses pembelajaran yang pada akhirnya mempengaruhi hasil belajar siswa. Hasil belajar siswa pada 3 muatan (Bahasa Indonesia, PPKn dan Matematika) yang didapatkan masih rendah. Berdasarkan nilai ulangan harian tema bermain di lingkunganku sub tema bermain di tempat wisata khususnya pada 3 muatan (Bahasa Indonesia, PPKn dan Matematika) sebagian siswanya masih belum mencapai nilai yang memuaskan. Dari 15 


\section{Peningkatan Keterampilan Bertanya dan Hasil Belajar Siswa Kelas 2 SDN Slungkep}

(Meiria Sylvi Astuti)

orang siswa baru 2 anak atau 13,33\% siswa yang nilainya sama atau lebih dari KKM (66).

Berdasarkan akar masalah yang ditemukan, faktor utama yang harus segera dicarikan solusinya adalah bagaimana meningkatkan keterampilan bertanya siswa dalam kegiatan pembelajaran sehingga siswa tidak hanya mendengar dan mencatat penjelasan guru, dan menjawab soal, tetapi juga mampu mengajukan pertanyaan, menyampaikan pendapat/ gagasan, menyimpulkan dan mengkomunikasikan pesan pelajaran baik dalam kelompok kecil maupun dalam kelas. Peningkatan keterampilan bertanya siswa pada akhirnya akan berpengaruh pula terhadap peningkatan hasil belajar siswa.

Salah satu solusi untuk meningkatkan keterampilan bertanya siswa adalah dengan menggunakan model Discovery Learning. Model Discovery Learning adalah suatu cara mengajar yang melibatkan siswa dalam proses kegiatan mental melalui tukar pendapat, dengan diskusi, seminar, membaca sendiri dan mencoba sendiri, agar anak dapat belajar sendiri.

Berdasarkan beberapa penelitian tindakan kelas, ternyata model Discovery Learning mampu meningkatkan keterampilan saintifik dan hasil belajar siswa. Hasil Penelitian yang dilakukan Agus Supriyadi (2012) menunjukkan bahwa penerapan model Discovery Learning mampu meningkatkan hasil belajar materi bentuk daun dan fungsinya pada siswa kelas IV di Sekolah Dasar Negeri 03 Sungai Ambawang. Sementara penelitian Asnahwati (2013) menunjukan bahwa penggunaan model Discovery Learning dapat meningkatkan hasil belajar peserta didik dalam pembelajaran IPA kelas III SD Bruder Melati Pontianak. Prysta Widhiyani (2013) menemukan bahwa melalui model Discovery Learning dapat meningkatkan Aktivitas dan Hasil Belajar Siswa Kelas III SDN Sumbersari 02 pada Pembelajaran Matematika Pokok Bahasan Segitiga dan Segiempat Tahun Pelajaran 2012-2013. Demikian halnya dengan penelitian Yusmanah (2012) penggunaan model Discovery dapat meningkatkan keterampilan bertanya pelajaran matematika kelas VI SD 34 Pontianak Kota.

Untuk memperbaiki proses dan hasil belajar siswa kelas 2 SDN Slungkep 03 akan diterapkan model pembelajaran Discovery Learning. Diharapkan setelah tindakan pembelajaran dilakukan, rata-rata tingkat keterampilan bertanya siswa tema tugasku sehari-hari pada 3 muatan (Bahasa Indonesia, PPKn dan Matematika) mencapai $\geq 70 \%$. Setelah siklus 2 dilakukan, nilai rata-rata ulangan harian tema tugasku sehari-hari pada 3 muatan (Bahasa Indonesia, PPKn dan Matematika) meningkat menjadi sekurang-kurangnya mencapai 70. Setelah dilakukan pembelajaran, diharapkan persentase jumlah siswa yang mencapai ketuntasan belajar tema tugasku sehari-hari pada semua muatan (Bahasa Indonesia, PPKn dan Matematika) meningkat menjadi 75\%. 


\section{KAJIAN PUSTAKA}

\section{Hakikat Pembelajaran Tematik Integratif/ Terpadu}

Pembelajaran tematik integratif merupakan pembelajaran yang menggunakan tema sebagai pemersatu kegiatan pembelajaran yang memadukan beberapa mata pelajaran sekaligus dalam satu kali tatap muka. Pelaksanaan pembelajaran tematik integratif berawal dari tema yang telah dipilih/ dikembangkan oleh guru yang sesuai dengan kebutuhan peserta didik. Jika dibandingkan dengan pembelajaran konvensional, pembelajaran tematik integratif ini lebih menekankan pada tema sebagai pemersatu berbagai mata pelajaran, dan keterkaitan berbagai konsep mata pelajaran. Muatan pelajaran yang dipadukan adalah muatan pelajaran PPKn, Bahasa Indonesia, IPS, IPA, Matematika, Seni Budaya dan Prakarya, serta Pendidikan Jasmani, Olah Raga dan Kesehatan. Dalam Kurikulum 2013, tema dikembangkan menjadi subtema dan satuan pembelajaran..

Tujuan pembelajaran tematik terpadu adalah: a) mudah memusatkan perhatian pada satu tema atau topik tertentu; b) mempelajari pengetahuan dan mengembangkan berbagai kompetensi muatan pelajaran dalam tema yang sama; c) memiliki pemahaman terhadap materi pelajaran lebih mendalam dan berkesan; d) mengembangkan kompetensi berbahasa lebih baik dengan mengkaitkan berbagai muatan pelajaran lain dengan pengalaman pribadi peserta didik; e) lebih bergairah belajar karena mereka dapat berkomunikasi dalam situasi nyata, seperti bercerita, bertanya, menulis sekaligus mempelajari pelajaran yang lain; f) lebih merasakan manfaat dan makna belajar karena materi yang disajikan dalam konteks tema yang jelas; g) guru dapat menghemat waktu, karena mata pelajaran yang disajikan secara terpadu dapat dipersiapkan sekaligus dan diberikan dalam 2 atau 3 pertemuan bahkan lebih dan atau pengayaan; dan h) budi pekerti dan moral peserta didik dapat ditumbuh kembangkan dengan mengangkat sejumlah nilai budi pekerti sesuai dengan situasi dan kondisi.

Implementasi Pembelajaran Tematik Terpadu melalui beberapa tahapan yaitu pertama guru harus mengacu pada tema sebagai pemersatu berbagai muatan pelajaran untuk satu tahun. Kedua guru melakukan analisis Standar Kompetensi Lulusan, Kompetensi Inti, Kompetensi Dasar dan membuat indikator dengan tetap memperhatikan muatan materi dari Standar Isi. Ketiga membuat hubungan pemetaan antara kompetensi dasar dan indikator dengan tema. Keempat membuat jaringan $\mathrm{KD}$, indikator. Kelima menyusun silabus tematik dan keenam membuat rencana pelaksanaan pembelajaran tematik terpadu dengan menerapkan pendekatan saintifik (Mawardi, 2014: 1-3 ). 
Peningkatan Keterampilan Bertanya dan Hasil Belajar Siswa Kelas 2 SDN Slungkep (Meiria Sylvi Astuti)

\section{Pendekatan Saintifik dan Keterampilan Bertanya}

Proses pembelajaran dapat dipadankan dengan suatu proses ilmiah, karena itu Kurikulum 2013 mengamanatkan esensi pendekatan saintifik dalam pembelajaran. Pendekatan saintifik diyakini sebagai titian emas perkembangan dan pengembangan sikap, keterampilan dan pengetahuan peserta didik. Kegiatan pembelajaran saintifik dilakukan melalui keterampilan proses mengamati, menanya, mencoba, mengasosiasi, dan mengomu-nikasikan.

Kegiatan "menanya" dalam kegiatan pembelajaran sebagaimana disampaikan dalam Permendikbud Nomor 81a Tahun 2013, adalah mengajukan pertanyaan tentang informasi yang tidak dipahami dari apa yang diamati atau pertanyaan untuk mendapatkan informasi tambahan tentang apa yang diamati (dimulai dari pertanyaan faktual sampai ke pertanyaan yang bersifat hipotetik). Pada keterampilan proses menanya guru dituntut memiliki keterampilan bertanya dasar maupun bertanya lanjut. Meskipun pada dasarnya guru melakukan kegiatan tanya jawab dengan siswa, namun tujuan sebenarnya adalah mengupayakan siswa memiliki kemampuan aktif bertanya. Kegiatan pembelajaran yang dilakukan pada langkah menanya ini berupa siswa mengajukan pertanyaan tentang informasi yang tidak dipahami dari objek yang diamatinya. Adapun kompetensi yang diharapkan dalam kegiatan ini adalah mengembangkan kreativitas, rasa ingin tahu, kemampuan merumuskan pertanyaan untuk membentuk pikiran kritis yang perlu untuk hidup cerdas dan belajar sepanjang hayat.

Secara etimologis keterampilan bertanya dapat diurai menjadi dua suku yaitu " terampil dan tanya". Menurut kamus besar Bahasa Indonesia "bertanya" berasal dari kata "tanya" yang berarti antara lain permintaan keterangan. Sedangkan ka-ta "terampil" yang berarti memilki arti "cakap" dalam menyelesaikan tugas atau mampu dan cekatan". Keterampilan bertanya adalah cara penyampaian suatu pelajaran melalui interaksi dua arah yaitu dari guru kepada siswa dan dari siswa kepada guru agar diperoleh jawaban kepastian materi melalui jawaban lisan guru atau siswa. Dalam mengajukan pertanyaan, guru memerlukan beberapa teknik, begitu juga pada siswa. Ketika siswa mengajukan pertanyaan pasti menggunakan teknik-teknik tertentu. Tehnik tersebut menunjukkan indikator keterampilan siswa di dalam bertanya. Indikator keterampilan bertanya siswa tersebut meliputi: substansi pertanyaan, frekuensi pertanyaan dalam 1 jam pelajaran, bahasa, suara dan kesopanan (Zaifbio, 2013).

\section{Model Pembelajaran Discovery Learning}

Discovery Learning adalah teori belajar yang didefinisikan sebagai proses 
pembelajaran yang terjadi bila pelajar tidak disajikan dengan pelajaran dalam bentuk finalnya, tetapi diharapkan mengorganisasi sendiri (Depdiknas, 2014). Model Discovery Learning adalah memahami konsep, arti, dan hubungan, melalui proses intuitif untuk akhirnya sampai kepada suatu kesimpulan. Model pembelajaran Discovery Learning memiliki beberapa langkah-langkah, di antaranya: stimulation, problem statement, data collecting,data processing, verivication dan generalization.

Pertama- tama siswa dihadapkan pada sesuatu yang menimbulkan kebingungannya, kemudian dilanjutkan untuk tidak memberi generalisasi, agar timbul keinginan untuk menyelidiki sendiri. Disamping itu guru dapat memulai kegiatan PBM dengan mengajukan pertanyaan, anjuran membaca buku, dan aktivitas belajar lainnya yang mengarah pada persiapan pemecahan masalah. Setelah dilakukan stimulasi langkah selanjutya adalah guru memberi kesempatan kepada siswa untuk mengidentifikasi sebanyak mungkin agenda- agenda masalah yang relevan dengan bahan pelajaran, kemudian salah satunya dipilih dan dirumuskan dalam bentuk hipotesis. Ketika eksplorasi berlangsung guru juga memberi kesempatan kepada para siswa untuk mengumpulkan informasi sebanyak-banyaknya yang relevan untuk membuktikan benar atau tidaknya hipotesis. Pengolahan data merupakan kegiatan mengolah data dan informasi yang telah diperoleh para siswa baik melalui wawancara, observasi, dan sebagainya, lalu ditafsirkan. Pada tahap verivication siswa melakukan pemeriksaan secara cermat untuk membuktikan benar atau tidaknya hipotesis yang ditetapkan tadi dengan temuan alternatif, dihubungkan dengan hasil data processing. Tahap generalisasi/ menarik kesimpulan adalah proses menarik sebuah kesimpulan yang dapat dijadikan prinsip umum dan berlaku untuk semua kejadian atau masalah yang sama, dengan memperhatikan hasil verifikasi.

Kelebihan model Discovery Learning diantaranya: a) Membantu siswa untuk memper-baiki dan meningkatkan keterampilan- keterampilan dan proses-proses kognitif; b) Menim-bulkan rasa senang pada siswa, karena tumbuhnya rasa menyelidiki dan berhasil; c) Menye-babkan siswa mengarahkan kegiatan belajarnya sendiri dengan melibatkan akalnya dan motivasi sendiri; d) Membantu siswa memperkuat konsep dirinya, karena memperoleh kepercayaan bekerja sama dengan yang lainnya; e) Berpusat pada siswa dan guru berperan sama- sama aktif mengeluarkan gagasan-gagasan; f) Membantu siswa menghilangkan skeptisme (keragu- raguan) karena mengarah pada kebenaran yang final dan tertentu atau pasti.

Di samping beberapa kelebihan, metode Discovery Learning juga memiliki beberapa kelemahan, di antarannya: a) Menimbulkan asumsi bahwa ada kesiapan pikiran untuk belajar; b) Bagi siswa yang kurang pandai, akan mengalami 


\section{Peningkatan Keterampilan Bertanya dan Hasil Belajar Siswa Kelas 2 SDN Slungkep}

(Meiria Sylvi Astuti)

kesulitan abstrak atau berfikir atau mengungkapkan hubungan antara konsepkonsep, yang tertulis atau lisan, sehingga pada gilirannya akan menimbulkan frustasi; c) Model ini tidak efisien untuk mengajar jumlah siswa yang banyak, karena membutuhkan waktu yang lama untuk membantu mereka menemukan teori atau pemecahan masalah lainnya; d) Harapan- harapan yang terkandung dalam metode ini dapat buyar berhadapan dengan siswa dan guru yang telah terbiasa dengan cara-cara belajar yang lama; e) Pengajaran discovery lebih cocok untuk me-ngembangkan pemahaman, sedangkan mengembangkan aspek konsep keterampilan dan emosi secara keseluruhan kurang mendapat perhatian (Kemendikbud, 2014).

\section{Hasil Belajar}

Hasil belajar adalah prestasi belajar yang dicapai siswa dalam proses kegiatan belajar mengajar dengan membawa suatu perubahan dan pembentukan tingkah laku seseorang. Untuk menyatakan bahwa suatu proses belajar dapat dikatakan berhasil, setiap guru memiliki pandangan masing-masing sejalan dengan filsafatnya. Namun untuk menyamakan persepsi sebaiknya kita berpedoman pada kurikulum yang berlaku saat ini yang telah disempurnakan, antara lain bahwa suatu proses belajar mengajar tentang suatu bahan pembelajaran dinyatakan berhasil apabila tujuan pembelajaran khususnya dapat dicapai.

Untuk mengetahui tercapai tidaknya tujuan pembelajaran khusus, guru perlu mengadakan tes formatif pada setiap menyajikan suatu bahasan kepada siswa. Penilaian formatif ini untuk mengetahui sejauh mana siswa telah menguasai tujuan pembelajaran khusus yang ingin dicapai. Fungsi penelitian ini adalah untuk memberikan umpan balik pada guru dalam rangka memperbaiki proses belajar mengajar dan melaksanakan program remedial bagi siswa yang belum berhasil. Karena itulah, suatu proses belajar mengajar dinyatakan berhasil apabila hasilnya memenuhi tujuan pembelajaran khusus dari bahan tersebut. Yang menjadi indikator utama hasil belajar siswa adalah sebagai berikut: a) Keter-capaian Daya Serap terhadap bahan pembelajaran yang diajarkan, baik secara individual maupun kelompok, biasanya dilakukan dengan penetapan Kriteria Ketuntasan Belajar Minimal (KKM); b) Perilaku yang digariskan dalam tujuan pembelajaran telah dicapai oleh siswa, baik secara individual maupun kelompok.

Hasil belajar yang dicapai oleh siswa di sekolah merupakan salah satu ukuran terhadap penguasaan materi pelajaran yang disampaikan. Peran guru dalam menyampaikan materi pelajaran dapat mempengaruhi hasil belajar siswa. Faktor- faktor yang mempengaruhi hasil belajar siswa penting sekali untuk diketahui, artinya dalam rangka membantu siswa mencapai hasil belajar yang seoptimal mungkin. Hasil belajar yang dicapai siswa dipengaruhi oleh dua faktor 
utama, yakni faktor dari dalam diri siswa dan faktor yang datang dari luar diri siswa, terutama kamampuan yang dimilikinya. Faktor kemampuan siswa besar sekali pengaruhnya terhadap keberhasilan belajar siswa yang dicapai.

Di samping faktor kemampuan yang dimiliki oleh siswa, juga ada faktor lain seperti motivasi belajar, ketekunan, sosial ekonomi, faktor fisik dan psikis. Sungguh pun demikian, hasil yang dapat diraih masih juga bergantung dari lingkungan, artinya ada faktor- faktor yang berada di luar dirinya yang dapat menentukan dan mempengaruhi hasil belajar yang dicapai. Salah satu lingkungan pelajaran yang dominan mempengaruhi hasil belajar siswa di sekolah adalah kualitas pengajaran. Yang dimaksud dengan kualitas pengajaran ialah tinggi rendahnya atau pun efektif tidaknya proses pembelajaran dalam mencapai tujuan pembelajaran. Salah satu indikator kualitas pengajaran adalah model pembelajaran yang digunakan guru (Ainamulyana, 2012).

\section{METODE PENELITIAN}

Penelitian tindakan kelas (PTK) ini dilakukan di SD Negeri Slungkep 03, Kecamatan Kayen Kabupaten Pati pada tema tugasku sehari-hari kelas 2 Semester 1 Tahun Pelajaran 2014/ 2015. Pelaksanaan penelitian tindakan kelas ini dilakukan melalui tahapan penyusunan proposal penelitian, penyusunan instrument, pelaksanaan tindakan dalam rangka pengumpulan data, analisis data dan pembahasan hasil penelitian serta penyusunan laporan PTK. Waktu pelaksanaan setiap tahap PTK adalah sebagai berikut: 1) penyusunan proposal penelitian dilakukan pada bulan Oktober tahun 2014; 2) Penyusunan instrumen PTK dilakukan pada November minggu ke -2 tahun 2014; 3) Pelaksanaan tindakan siklus 1 dilakukan pada November minggu ke-4 tahun 2014. Siklus 2 dilakukan pada Desember minggu ke-1 tahun 2014.

Subyek yang dilibatkan dalam penelitian tindakan kelas ini adalah siswa kelas 2 yang berjumlah 15 yaitu 12 laki-laki dan 3 perempuan. Sumber data primer berasal dari hasil pengukuran variabel penelitian tindakan kelas berikut: 1) skor hasil belajar siswa sebagai cerminan dari penguasaan tema tugasku sehari-hari, 2) skor keterampilan bertanya siswa. Sumber data sekunder berasal dari hasil pengamatan teman sejawat terhadap aktivitas pembelajaran, yang terdiri dari: 1) tingkat aktivitas guru dan 2) tingkat aktivitas siswa dalam pembelajaran.

Teknik pengumpulan data dalam penelitian ini menggunakan teknik tes dan non tes. Instrumen tes berupa instrumen pengumpulan data hasil belajar siswa tema tugasku sehari-hari menggunakan test hasil belajar. Instrumen non tes berupa pengumpulan data mengenai keterampilan bertanya siswa menggunakan rubik keterampilan bertanya siswa. Kisi-kisi instrumen pengukuran hasil belajar tema 
tugasku sehari-hari mencakup 15 item soal, terdiri dari soal Bahasa Indonesia (item no. 1- 5), PKn (item no. 6-10) dan soal Matematika (item no. 11-15). Kisikisi instrumen pengukuran keterampilan bertanya siswa mencakup mencakup 5 aspek, yaitu aspek substansi pertanyaan (item no. 1), frekuensi pertanyaan dalam 1 jam pelajaran (item no. 2), bahasa (item no. 3), suara (item no. 4), dan kesopanan (item no. 5).

Analisis data yang digunakan adalah teknik analisis deskriptif komparatif. Data kuantitatif yang diperoleh di deskripsikan dalam bentuk kata- kata atau penjelasan. Baik data yang diperoleh dari hasil tes siswa maupun rubik keterampilan bertanya siswa. Selanjutnya dilakukan komparasi data setiap siklus untuk memastikan ada tidaknya peningkatan hasil belajar siswa dan peningkatan keterampilan bertanya siswa. Sebagai tolok ukur keberhasilan pelaksanaan penelitian tindakan kelas ini ditetapkan indikator kinerja sebagi berikut:

Langkah-langkah pembelajaran dikatakan berhasil jika skor aktivitas guru dan siswa mencapai kategori baik; 2) Keterampilan bertanya siswa pada tema tugasku sehari-hari kelas 2 SDN Slungkep 03 Tahun Pelajaran 2014/2015 mencapai $\geq 80$ $\%$ atau masuk dalam kategori tinggi; 3) Hasil belajar siswa dikatakan meningkat jika jumlah siswa yang sudah mencapai ketuntasan belajar pada 3 muatan (Bahasa Indonesia, PPKn dan Matematika) mencapai $\geq 70 \%$. Prosedur PTK ini terdiri dari empat tahapan yang saling terkait dan berkesinambungan, yaitu perencanaan, tindakan, observasi serta refleksi (Arikunto, 2007).

\section{HASIL DAN PEMBAHASAN}

\section{Deskripsi Hasil Tiap Siklus dan Antar Siklus}

Setelah melakukan analisa terhadap data yang diperoleh dari dua siklus yang dilaksanakan, maka dapat disimpulkan bahwa penggunaan model Discovery Learning pada tema tugasku sehari-hari menunjukkan peningkatan Keterampilan bertanya siswa dan ketuntasan hasil belajar siswa.

Tabel 1 merangkum komparasi tingkat Keterampilan bertanya siswa siklus 1 sampai siklus 2. Data pada tabel tersebut menunjukkan peningkatan frekuensi keterampilan bertanya siswa dari kategori sedang menjadi kategori tinggi. Pada siklus I frekuensi kategori sedang hanya diperoleh 4 siswa saja sementara diakhir siklus II ternyata keterampilan bertanya seluruh siswa mampu mencapai kategori tinggi. Apabila dibandingkan dengan kondisi awal sebelum dilakukan tindakan penelitian, maka jelas terlihat adanya kemajuan yang cukup signifikan mengingat sebelum tindakan dilakukan keterampilan bertanya mereka sangat rendah. 
Tabel 1.

Perbandingan Frekuensi Keterampilan Bertanya

Siswa Siklus I dan Siklus II

\begin{tabular}{|l|c|c|}
\hline Kategori & Frekuensi Siklus I & Frekuensi Siklus II \\
\hline Rendah & 0 & 0 \\
\hline Sedang & 4 & 0 \\
\hline Tinggi & 11 & 15 \\
\hline Jumlah & 15 & 15 \\
\hline
\end{tabular}

Peningkatan hasil belajar siswa dalam pembelajaran tema tugasku seharihari menggunakan model Discovery Learning pada siklus I dan siklus II dapat dilihat dalam tabel 2. Dari tabel tersebut dapat dilihat adanya peningkatan hasil belajar siswa seiring dengan digunakannya model pembelajaran Discovery Learning.

Tabel 2 memperlihatkan adanya peningkatan hasil belajar siswa dari siklus I ke siklus II untuk masing-masing muatan mata pelajaran. Rata-rata presentase ketuntasan siswa untuk masing-masing muatan mata pelajaran sudah mencapai $80 \%$. Akan tetapi ada pula beberapa siswa yang masih belum memperlihatkan kemajuan hasil belajarnya, hal ini disebabkan karena siswa tersebut memang belum mampu menyerap materi dengan baik mengingat beberapa siswa tersebut belum bisa membaca dengan lancar.

Tabel 2.

Perbandingan Frekuensi Hasil Belajar Siswa Siklus I dan Siklus II

\begin{tabular}{|l|l|l|l|l|l|l|}
\hline \multirow{3}{*}{ Kategori } & \multicolumn{6}{|c|}{ Muatan Mata Pelajaran } \\
\cline { 2 - 8 } & \multicolumn{2}{|c|}{$\begin{array}{c}\text { Bahasa } \\
\text { Indonesia }\end{array}$} & \multicolumn{2}{c|}{ PPKn } & \multicolumn{2}{c|}{ Matematika } \\
\cline { 2 - 8 } & $\begin{array}{c}\text { Siklus } \\
\text { I }\end{array}$ & $\begin{array}{c}\text { Siklus } \\
\text { II }\end{array}$ & $\begin{array}{c}\text { Siklus } \\
\text { I }\end{array}$ & $\begin{array}{c}\text { Siklus } \\
\text { II }\end{array}$ & $\begin{array}{c}\text { Siklus } \\
\text { I }\end{array}$ & $\begin{array}{c}\text { Siklus } \\
\text { II }\end{array}$ \\
\hline Tuntas & 11 & 13 & 10 & 13 & 8 & 12 \\
\hline Belum & 4 & 2 & 5 & 2 & 7 & 3 \\
\hline Jumlah & 15 & 15 & 15 & 15 & 15 & 15 \\
\hline \% Tuntas & $\mathbf{7 3 , 3 3}$ & $\mathbf{8 6 , 6 7}$ & $\mathbf{6 6 , 6 7}$ & $\mathbf{8 6 , 6 7}$ & $\mathbf{4 6 , 6 7}$ & $\mathbf{8 0 , 0 0}$ \\
\hline \% Belum & $\mathbf{2 6 , 6 7}$ & $\mathbf{1 3 , 3 3}$ & $\mathbf{3 3 , 3 3}$ & $\mathbf{1 3 , 3 3}$ & $\mathbf{5 3 , 3 3}$ & $\mathbf{2 0 , 0 0}$ \\
\hline
\end{tabular}


Grafik di bawah ini memperlihatkan dengan jelas adanya peningkatan ketuntasan hasil belajar dari siswa siklus I ke siklus II pada masing-masing muatan pelajaran.

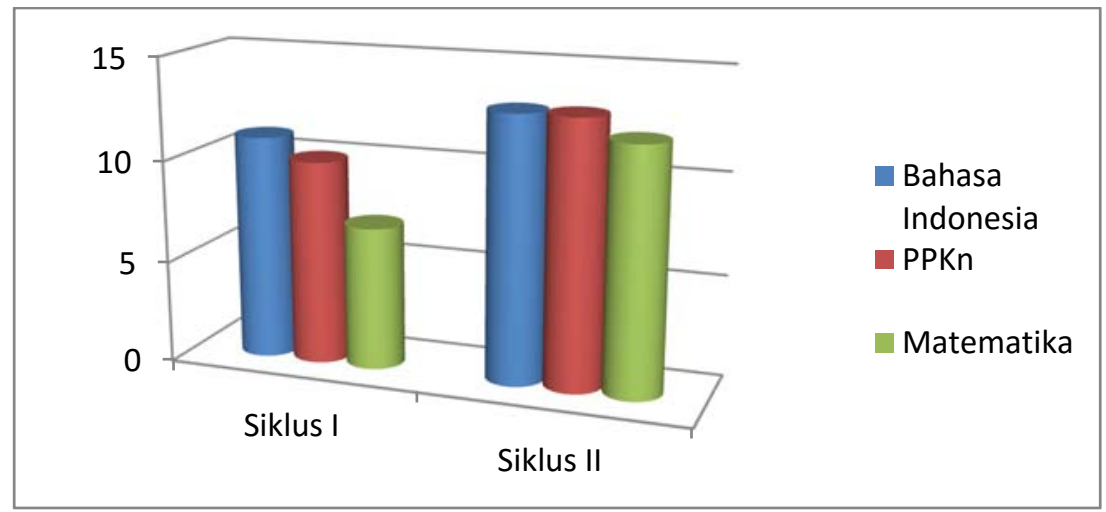

Gambar Grafik Peningkatan Ketuntasan Hasil Belajar Siswa Siklus I dan II

Berdasarkan hasil penelitian tindakan kelas yang telah dilakukan, secara garis besar dengan dilaksanakannya model pembelajaran Discovery Learning pada pembelajaran tema tugasku sehari-hari kelas 2 SDN Slungkep 03 ternyata keterampilan bertanya dan hasil belajar siswa tersebut dapat ditingkatkan.

\section{Temuan Penelitian dan Pembahasan}

\section{Keberhasilan model Discovery Learning dalam meningkatkan keterampilan bertanya siswa}

Data pada tabel keterampilan bertanya siswa siklus 1 dan siklus 2 menunjukkan temuan rerata keterampilan bertanya siswa pada siklus 117,27 (kategori sedang) menjadi 20,59 (kategori tinggi). Temuan ini mengindikasikan adanya peningkatan keterampilan bertanya siswa tema tugasku sehari-hari sebesar 19,22\% diakhir siklus 2. Hasil penelitian ini sudah sesuai dengan indikator kinerja dimana keterampilan bertanya siswa mampu mencapai kategori tinggi.

Keberhasilan penelitian ini bermakna bahwa siswa telah terampil dalam menyampaikan pertanyaan dimana indikator keterampilan bertanya siswa tersebut meliputi substansi pertanyaan, frekuensi pertanyaan dalam 1 jam pelajaran, bahasa, suara dan kesopanan. Hasil penelitian ini sejalan dengan penelitian Yusmanah (2012) bahwa penggunaan model Discovery dapat meningkatkan keterampilan bertanya pelajaran matematika kelas VI SD 34 Pontianak Kota. Dalam pelaksanaan model Discovery Learning terutama tahap 
stimulation ternyata memang mampu merangsang siswa untuk aktif bertanya apabila langkah tersebut dilakukan dengan benar. Hal ini berarti penggunaan model Discovery Learning dapat meningkatkan keterampilan siswa dalam bertanya.

\section{Keberhasilan model Discovery Learning dalam meningkatkan hasil belajar} siswa

Data pada grafik hasil belajar siswa siklus 1 dan siklus 2 menunjukkan temuan bahwa jumlah siswa yang tuntas untuk muatan Bahasa Indonesia siklus I sebesar 73,33\% menjadi 86,67\% diakhir siklus II. Muatan PPKn jumlah siswa yang tuntas dari siklus I sebesar $66,67 \%$ menjadi $86,67 \%$ diakhir siklus II. Sementara untuk muatan Matematika, jumlah siswa tuntas dari siklus I sebesar 46,67\% menjadi 80,00\% diakhir siklus II. Hasil tersebut membuktikan bahwa penerapan model Discovery Learning mampu meningkatkan ketuntasan hasil belajar siswa dalam kategori tinggi rata-rata sebesar 18,19 \% - 33,33\%.

Hasil penelitian ini sejalan dengan Prysta Widhiyani (2013) yang menemukan bahwa melalui model Discovery Learning dapat meningkatkan Aktivitas dan Hasil Belajar Siswa Kelas III SDN Sumbersari 02 pada Pembelajaran Matematika Pokok Bahasan Segitiga dan Segiempat Tahun Pelajaran 2012-2013. Oleh karena itu penelitian ini dapat dikatakan berhasil.

\section{SIMPULAN DAN SARAN}

\section{Simpulan}

Berdasarkan hasil pembahasan dan kajian data-data dari tiap siklus (siklus I dan siklus II) dalam pembelajaran tema tugasku sehari-hari menggunakan model Discovery Learning di SDN Slungkep 03, Kecamatan Kayen, Kabupaten Pati melalui Penelitian Tindakan Kelas dapat ditarik kesimpulan yaitu:

1. Langkah-langkah model pembelajaran Discovery Learning dalam rangka meningkatkan keterampilan bertanya dan hasil belajar siswa kelas 2 SDN Slungkep 03 diantaranya: a.Stimulation (stimulasi/ pem-berian rangsangan), b. Problem statement (pernyataan/ identifikasi masalah), c. Data collection (Pengumpulan Data), d. Data Processing (Pengolahan Data), e. Verification (Pembuktian), f. Generalization (menarik kesim-pulan/ generalisasi).

2. Dengan menggunakan model pembelajaran Discovery Learning dapat meningkatkan keterampilan bertanya siswa siklus I dari kategori sedang menjadi kategori tinggi diakhir siklus II sebesar 19,22\%. Selain itu model tersebut juga dapat meningkatkan hasil belajar siswa kelas 2 SDN. 
Slungkep 03 semester 1 tahun Ajaran 2014/ 2015. Hal ini dibuktikan dengan hasil dari siklus I (sub tema tugasku sehari-hari di rumah) dan siklus II (sub tema tugasku sehari-hari di sekolah) yang memperlihatkan adanya peningkatan ketuntasan hasil belajar siswa untuk 3 muatan mata pelajaran (Bahasa Indonesia, PPKn dan Matematika). Jumlah siswa yang tuntas untuk muatan Bahasa Indonesia siklus I 73,33\% menjadi $86,67 \%$ diakhir siklus II. Muatan PPKn jumlah siswa yang tuntas dari siklus I 66,67\% menjadi $86,67 \%$ diakhir siklus II. Sementara untuk muatan Matematika, jumlah siswa tuntas dari siklus I 46,67\% menjadi $80,00 \%$ diakhir siklus II. Hasil tersebut membuktikan bahwa penerapan model Discovery Learning mampu meningkatkan ketuntasan hasil belajar siswa dalam kategori tinggi rata-rata sebesar $18,19 \%-33,33 \%$.

\section{Saran}

Dengan adanya uraian dari kesimpulan diatas maka penulis memberikan saran kepada berbagai pihak antara lain :

1. Bagi siswa.

Rendahnya keterampilan bertanya siswa kelas 2 dapat di atasi apabila dalam melaksanakan langkah model Discovery Learning khususnya stimulation benar-benar dilaksanakan dengan baik. Siswa diharapkan sungguh-sungguh dalam melaksanakan kegiatan penga-matan sehingga kegiatan tanya jawab akan berlangsung sesuai harapan. Untuk siswa yang belum tuntas sebaiknya dilakukan perbaikan atau siklus selanjutnya sampai semua siswa tuntas.

2. Bagi para guru.

Guru harus mempersiapkan rencana pembelajaran dengan lebih baik untuk menunjang efektivitas proses pembelajaran. Selain itu guru hendaknya. Guru diharapkan dapat menerapkan model Discovery Learning menggunakan media pembelajaran yang mampu memikat dan menarik perhatian siswa misalnya LCD karena model tersebut terbukti dapat meningkatkan keterampilan bertanya dan hasil belajar siswa tema tugasku sehari-hari.

3. Bagi sekolah dan Dinas Pendidikan.

Sekolah hendaknya menyediakan media pembelajaran yang mendukung untuk mempermudah guru dalam menyampaikan materi pembelajaran. Dinas Pendidikan juga hendaknya lebih mengintensifkan pendidikan dan pelatihan bagi guru untuk meningkatkan profesionalismenya. 


\section{DAFTAR PUSTAKA}

Ainamulyana. 2012. Pengertian Hasil Belajar dan Faktor. Http://ainamulyana. blogspot.com/2012/01/pengertian-hasil-belajar-dan-faktor.html. (16 Januari 2012).

Arikunto, Suharsimi. 2007. Penelitian Tindakan Kelas. Jakarta : Bumi Aksara

Asnahwati. 2013. Meningkatkan Hasil Belajar Siswa Materi Cuaca Melalui Metode Pembelajaran Discovery pada Mata Pelajaran IPA Kelas III SD Bruder Melati Pontianak. Jurnal PGSD FKIP Univer-sitas Tanjungpura Pontianak. 7(1): 2-9.

Azwar, Syaifuddin. 2011. Reliabilitas dan Validitas. Yogyakarta: Pustaka Pelajar.

Depdiknas, 2007. Kamus Besar Bahasa Indonesia.

Husen. 2013. Pengaruh Pemberian Reward Terhadap Kemampuan Ber-tanya pada Mata Pelajaran Geografi Topik Hidrosfer. Skripsi. Jurusan Fisika, Prodi. S1 Geografi, Fakultas Matematika dan Ilmu

Pengetahuan Alam, Universitas Negeri Gorontalo .

Kemendikbud, 2014. Model Pembelajaran Penemuan (Discovery Learning). Jakarta : Badan Pengembangan SDM Pendidikan dan Kebudayaan dan Penjaminan Mutu Pendidikan.

Mawardi, 2014. Penyesuaian Komponen-Komponen PTK Setelah Pem-berlakuan Kurikulum SD/MI TAHUN 2013. UKSW Salatiga.

Supriyadi, Agus. 2013. Peningkatan Hasil Belajar Metode Discovery Pembelajaran Ipa Kelas IV SDN 03 Sungai Ambawang Kubu Raya. Jurnal PGSD FKIP Universitas Tanjungpura Pontianak. 5(1): 2-14.

Widhiyani, Prysta. 2013. Pembelajaran Matematika Melalui Metode Discovery Learning untuk Meningkatkan Aktivitas dan Hasil Belajar Siswa Kelas III SDN Sumbersari 02 Jember Pokok Bahasan Segitiga dan Segiempat Tahun Pelajaran 2012-2013. Skripsi PGSD FKIP Universitas Jember. 1113.

Yusmanah. 2013. Peningkatan Keterampilan Bertanya Dengan Menggunakan Metode Penemuan Terbimbing Dalam Pembelajaran Matematika. Jurnal PGSD FKIP Universitas Tanjungpura Pontianak. 5(2): 3-21.

Zaifbio. 2013. Keterampilan Bertanya. Http://zaifbio.wordpress.com/ 2013/05/14/keterampi-lanbertanya/.(14 Mei 2013). 